ReVISTA de BIOLOGía TROPICAL

\title{
Holopothrips chaconi sp.n. (Thysanoptera: Phlaeothripinae) from leaf-vein galls on Piper species (Piperaceae) in Costa Rica
}

\author{
Steven Zamora ${ }^{1}$, Paul Hanson ${ }^{1} \&$ Laurence A. Mound ${ }^{2}$ \\ 1. Escuela de Biología, Universidad de Costa Rica, San Pedro 11501-2060 San José, Costa Rica; \\ steven.zamora@gmail.com, phanson91@gmail.com \\ 2. Australian National Insect Collection, CSIRO, Canberra, Australia, 2601; Laurence.mound@csiro.au
}

Received 31-X-2014. Corrected 05-V-2015. Accepted 01-VI-2015.

\begin{abstract}
Most species of the Neotropical genus Holopothrips are associated with plant galls but very little is known about their biology. Here, we provide observations on the biology of a new species of Holopothrips associated with leaf-vein galls on four species of Piper at a cloud forest site (Zurquí de Moravia) in Costa Rica. This species colonized the galls soon after the gall-inducing cecidomyiid or one of its parasitoids emerged, and several generations of thrips appeared to occupy the empty galls. A total of 175 empty galls from 34 leaves were collected, brought to the laboratory for dissection under the microscope, and the contents quantified. Holopothrips occupied approximately $75 \%$ of the galled leaves and among the latter they occupied about $40 \%$ of the galls. Every combination of adults, nymphs and eggs was found, which implies that adult thrips move in and out of galls, and possibly do not defend their galls from invasion by other members of their species. However, when disturbed, both nymphs and adults raise the tip of their abdomen and emit a distinctive odor, suggesting a defensive reaction against potential predators. Preliminary evidence suggests that they feed on gall tissue lining the inner cavity and spend very little time outside the galls. The thrips is described as a new species, and is one of only four known species of Holopothrips to have the unusual condition of two pairs of epimeral setae on the pronotum. This new species was compared to these other three Holothrips species, and the remarkable variation of the female spermatheca and the male sternal pore plate is illustrated. Further research is needed to confirm that several generations of thrips occupy empty galls, to determine whether adult thrips do indeed move between galls, and to explore in greater detail their possible chemical defense. Rev. Biol. Trop. 63 (4): 1035-1042. Epub 2015 December 01.
\end{abstract}

Key words: leaf galls, Piper species, Holopothrips new species, spermatheca structure.

Holopothrips is an unusual genus, in terms both of the structure and the biology of the 33 listed species (ThripsWiki, 2015). Most of these species are from the Neotropics, but with a few found in Mexico and the Caribbean islands and one as far North as the Florida everglades (Mound \& Marullo, 1996). Most species seem to be associated with plant galls and a few appear to be gall-inducers, although demonstration of this is usually lacking.

Most Holopothrips species have an extra pair of curved setae on the anterior abdominal tergites in addition to the two pairs of curved wing-retaining setae that are typical of Phlaeothripidae. The females usually have the spermatheca remarkably enlarged and curved, quite unlike that of other females in this family. The purpose of this investigation was to describe the biology of a new species of Holopothrips that breeds in Costa Rica on the leaves of four Piper species, specifically within the abandoned galls of a cecidomyid (Diptera) species. A similar association is recorded for Holopothrips inquilinus (Bournier) from Guadeloupe (Bournier, 1993), but in general little is known about the biology of species in this genus. 


\section{MATERIALS AND METHODS}

Observations on biology were carried out from November 2013 to September 2014 at Zurquí de Moravia, San José province, Costa Rica, in a mid-elevation $(1600 \mathrm{~m})$ cloud forest $\left(10^{\circ} 03^{\prime} 03^{\prime \prime} \mathrm{N}-84^{\circ} 00^{\prime} 22^{\prime}\right.$ W). A total of 175 abandoned galls were collected from 34 Piper leaves from April to September, 2014, distributed as follows: 88 galls on 8 leaves (25 April), 57 galls on 11 leaves (28 May), 27 galls on 4 leaves (11 July), and 3 galls on 1 leaf (24 September). The leaves with galls were brought to the laboratory for dissection under the microscope and the different life history stages of thrips were then quantified.

Most, if not all Piper species produce minute food bodies (pearl bodies) on the under surface of the leaf, which are presumably offered as a reward to small, potentially beneficial arthropods (Gastreich \& Gentry, 2004), and one ant species (Pheidole bicornis Forel) induces food body production inside the petiolar sheaths of certain Piper species (Risch \& Rickson, 1981). We therefore examined galls inhabited by thrips for the presence of food bodies and tested the possibility that adult thrips leave the gall to forage on widely scattered food bodies. Eight adult thrips were placed in ependorf vials, one per vial, together with a small $(5 \mathrm{~mm} \times 5 \mathrm{~mm})$ piece of leaf containing a food body in each vial. In addition, two galls occupied by thrips were placed in separate $5 \mathrm{~cm}$ diameter glass petri dishes, with a piece of leaf containing a food body positioned over the entrance to the gall.

The description of the new species was based on specimens slide-mounted into Canada balsam (Mound \& Marullo, 1996), and examined with a Leica DM2500 differential interference microscope, with photomicrographs processed through Automontage and Photoshop software. The new species was compared with specimens of the genus Holopothrips in the Natural History Museum, London, and the Australian National Insect Collection, Canberra. The holotype was deposited in the Natural History Museum, with paratypes in the Museo de Zoología of the Universidad de Costa Rica and in the Australian National Insect Collection.

\section{RESULTS}

Host associations: The new species of Holopothrips described below was found in abandoned galls of an undescribed species of Zalepidota (Diptera: Cecidomyiidae). The galls induced by this cecidomyiid consist of swellings of the leaf veins (especially the midvein) on certain species of Piper (Piperaceae). These galls occurred on the undersurface of leaves and were approximately $1.5 \mathrm{~mm}$ wide and 6 $\mathrm{mm}$ long, although several galls often occurred adjacent to one another in a series along the length of a vein (Fig. 1). Of the eight to ten species of Piper observed at the study site, these galls were seen only on four species: $P$. bredenmeyeri, $P$. lanosibracteum, $P$. torresanum, and an undetermined species in the $P$. epyginium - $P$. phaneropus - P. umbricula complex. Although other types of Piper galls occurred at the study site, we did not encounter Holopothrips in any of these other galls. Galls on other plant taxa were less thoroughly examined.

Life history: The thrips species was found in empty galls previously inhabited by the cecidomyiid or by one of its parasitoids, Chrysonotomyia conostegiae Hansson (Hymenoptera: Eulophidae) being one of the principal parasitoids reared from this gall. Our preliminary observations suggest that new galls begin forming, or at least become visible, in September, and that adult cecidomyiids and parasitoids emerge in February and March. The thrips began colonizing the empty galls by the middle of March, just a few weeks after the galls had been abandoned. Recently colonized galls contained just one or two adults with eggs, whereas older galls generally contained some combination of adults, nymphs and eggs (Fig. 2 and Fig. 3). Although we did not obtain data on leaf longevity or the maximum time that these thrips can continue to inhabit the galls, leaves with old galls harboring thrips appear to remain 

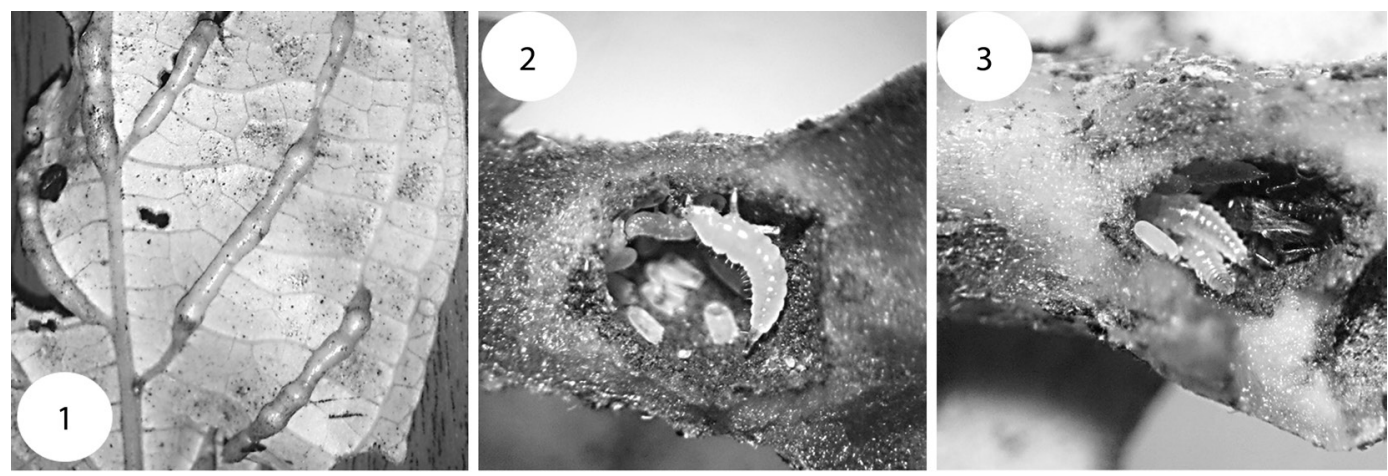

Fig. 1-3. (1). Leaf-vein galls on Piper sp. (P. epyginium - P. phaneropus - P. umbricula complex): underside of leaf showing galls induced by Zalepidota sp. (Diptera: Cecidomyiidae) [Scale-bar $=5 \mathrm{~mm}$. (2) Nymph of Holopothrips chaconi in dissected gall [Scale-bar $=2 \mathrm{~mm}$ ]. (3) Adult, nymphs and eggs of H. chaconi $[$ Scale-bar $=2 \mathrm{~mm}]$.

on the plant at least until the next generation of recently abandoned galls becomes available the following year.

On 25 April 2014, 8 leaves with galls were collected and 7 of these leaves had at least some galls that harbored thrips; on the 7 leaves with thrips there were a total of 80 galls, 33 with thrips, or $41 \%$ of the galls. On 28 May 2014, 11 leaves with galls were collected, but only 5 of these had galls harbored thrips; on these 5 leaves there were a total of 38 galls, 15 with thrips, or $39 \%$. The numbers of adults, nymphs and eggs found inside the galls on each of these leaves is shown in Table 1. Galls with thrips were also collected on 11 July and 24 September, but in very small numbers, probably because we had previously collected the most readily observable galls at the study site. Summing the results from all dates, approximately $75 \%$ of the galled leaves harbored thrips and on these leaves about $40 \%$ of the galls contained thrips. Among the galls containing thrips, $63 \%$ had adults, $60 \%$ had nymphs and $54 \%$ had eggs. When adults were present in a gall there were usually just 1 or 2, but one gall had 5 adults (with no nymphs or eggs) and one had 4 (again with no nymphs or eggs). The number of nymphs present in an individual gall was much more variable, up to a 11 in one case (this gall had no adults or eggs). The maximum number of eggs found in an individual gall was 10 (in this case there was
TABLE 1

Twelve leaves of Piper spp. having galls inhabited by Holopothrips chaconi collected on 25 April 2014 (first seven) and 28 May 2014 (last five), showing total number of galls with thrips per leaf versus total number of galls on that leaf, and number of adults, nymphs and eggs per leaf

\begin{tabular}{cccc}
$\begin{array}{c}\text { \# Galls with } \\
\text { thrips / total galls }\end{array}$ & \# Adults & \# Nymphs & \# Eggs \\
$2 / 4$ & 4 & 0 & 2 \\
$14 / 22$ & 6 & 29 & 29 \\
$3 / 10$ & 2 & 4 & 20 \\
$1 / 3$ & 1 & 6 & 7 \\
$2 / 11$ & 1 & 3 & 7 \\
$5 / 12$ & 8 & 0 & 0 \\
$6 / 18$ & 14 & 3 & 4 \\
$2 / 4$ & 0 & 7 & 3 \\
$5 / 12$ & 4 & 9 & 7 \\
$3 / 8$ & 3 & 0 & 2 \\
$3 / 3$ & 0 & 13 & 0 \\
$2 / 11$ & 3 & 0 & 1 \\
Total & & & \\
$48 / 118$ & 46 & 74 & 82 \\
\hline
\end{tabular}

also one adult present). Every possible combination of adults, nymphs and eggs was found but only 2 galls ( $4 \%$ of the total) had just eggs present. This possibly implies that adult thrips move in and out of galls, and may not defend their galls from invasion by other members of their species. However, when disturbed, such as when galls are dissected, both nymphs and 
adults raise the tip of their abdomen and emit a distinctive odor, suggesting a defensive reaction against potential predators.

Although not quantified, we occasionally observed that the number of empty egg shells in a gall greatly exceeded the number of nymphs and adults present. We also observed several instances of galls containing differentsized nymphs. These observations and the data presented above suggest that eggs are laid at different times and that the galls continue to be occupied by successive generations of thrips. It is also possible that some adult offspring remain in their maternal galls but further research is required to substantiate these aspects of the biology.

Feeding: Preliminary observations suggest that the thrips feed on tissue lining the inner cavity of empty galls. In the field we never observed these thrips outside the galls, although no observations were carried out at night. Leaves with galls inhabited by thrips were maintained in transparent plastic bags in the laboratory and just a few adults began to abandon the galls, but even then, only after 24 hours. Galls inhabited by thrips were dissected under the microscope and no evident fungal growth was seen. Nor were food bodies ever observed inside these galls. When adult thrips were placed with leaf pieces containing food bodies, all of the latter were still intact after 24 hours. In an identical experiment done with small coccinellid beetles known to feed on these food bodies, the latter were readily consumed in less than 30 minutes, the membrane of the food body collapsing after its contents were consumed. These results suggest that the thrips do not consume food bodies that are present on Piper leaves.

\section{Holopothrips chaconi sp.n.}

(Fig. 4, Fig. 5, Fig. 6, Fig. 7, Fig. 8, Fig. 9 y Fig. 10)

Female macroptera: Body and legs light brown, tarsi and fore tibiae almost yellow; antennal segment I and basal half of II as dark as head, III yellowish brown, IV-VIII light brown; major setae not dark, fore wings very weakly shaded.

Head slightly longer than wide, weakly expanded behind large eyes with cheeks parallel; eyes surrounding closely spaced ocelli; postocular setae long and weakly capitate; vertex weakly reticulate medially; maxillary stylets retracted to posterior margin of eyes, about one eighth of head width apart with small maxillary bridge (Fig. 4). Antennae 8-segmented (Fig. 7); segment III with 2 sense cones each slightly longer than 0.5 of the segment width; IV with 2 similar sense cones and a smaller dorsal one that is about half as long as the major sense cones; surface of these segments very weakly sculptured; segment VIII weakly constricted to base. Pronotum with notopleural sutures complete or incomplete; anteromarginal setae acute, no larger than discal setae, anteroangulars similar but slightly longer, remaining major setae long and blunt to weakly capitate, epimera with 2 pairs (Fig. 8). Fore tarsus with no tooth. Mesonotum weakly reticulate, lateral setae well-developed. Metanotum reticulate (Fig. 5), with 1 or 2 pairs of small setae on anterior half, median setae small and acute. Prosternal basantra absent, ferna transverse but not meeting medially, mesopresternum transversely boat-shaped; metathoracic sternopleural sutures weak. Fore wings parallel sided, with 5-8 duplicated cilia, and 3 long sub-basal setae with blunt apices. Pelta triangular with margins eroded irregularly; tergites very weakly sculptured medially, II-VII with 2 pairs of sigmoid wing-retaining setae, also 1 pair (rarely 0 or 2) of additional similar setae anterolaterally (Fig. 6), lateral major setae with apices blunt; tergite IX major setae acute, almost as long as tube, intermediate pair of setae short. Sternites with 8-10 small discal setae in transverse row, median marginal setal pair longer than lateral pair; spermatheca swollen and bulbous (Fig. 10).

Measurements (holotype female): Body length $2400 \mu \mathrm{m}$. Head, length $225 \mu \mathrm{m}$; width $200 \mu \mathrm{m}$; postocular setae $75 \mu \mathrm{m}$. Pronotum, 


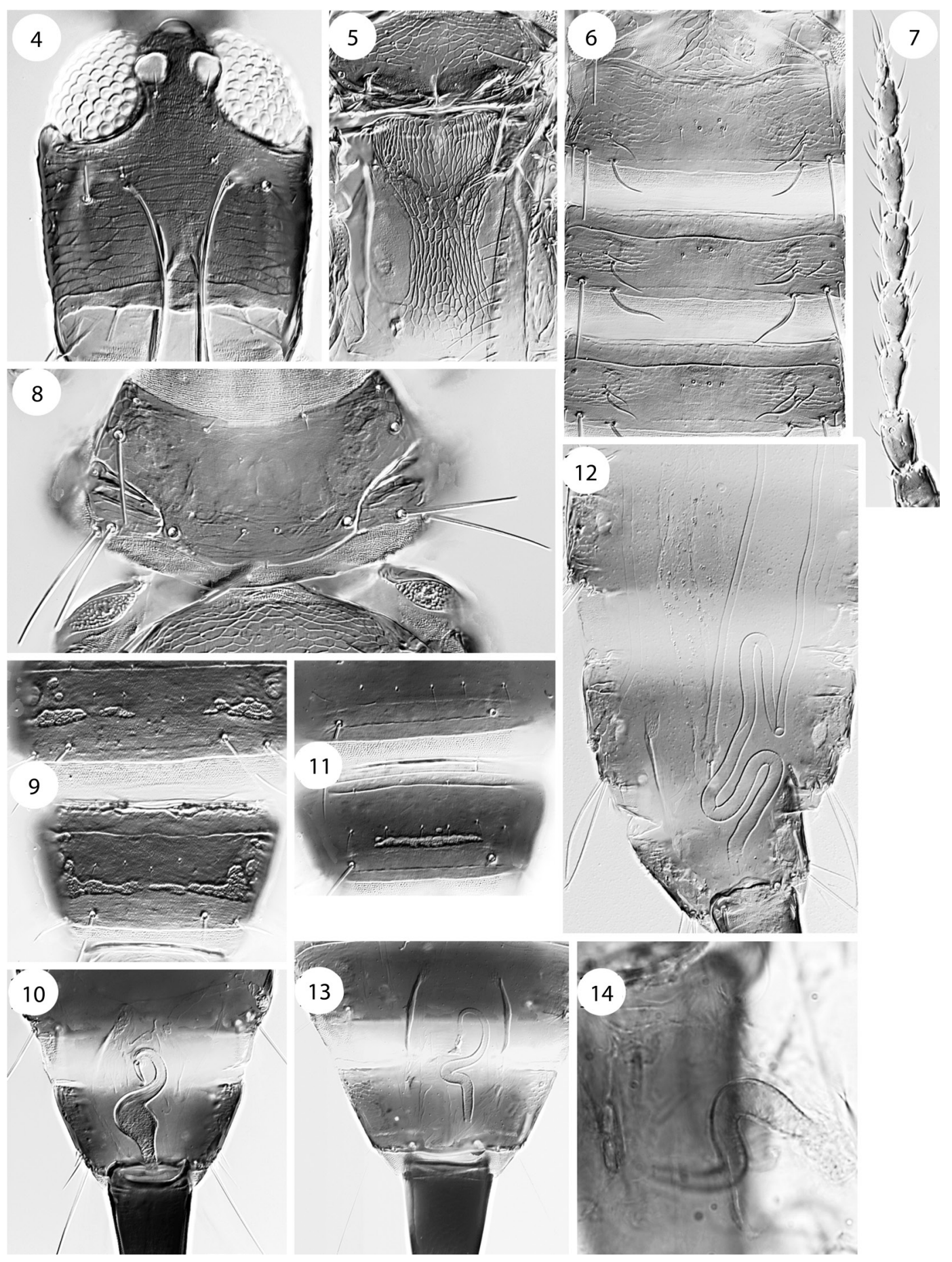

Figs. 4-14. Holopothrips chaconi $[$ Scale-bars = $0.05 \mathrm{~mm}$ ]: (4) head; (5) meso and metanota; (6) abdominal tergites I-IV; (7) antenna; (8) pronotum; (9) male sternites VII-VIII; (10) female spermatheca. (11) $H$. conducans, male sternites VII-VIII. (12) H. tillandsiae, female spermatheca. (13) H. conducans, female spermatheca. (14) H. inquilinus female spermatheca. 
length $120 \mu \mathrm{m}$; width $260 \mu \mathrm{m}$; major setae-am $15 \mu \mathrm{m}$, aa $20 \mu \mathrm{m}, \mathrm{ml} 80 \mu \mathrm{m}$, epim $125 \mu \mathrm{m}$, $100 \mu \mathrm{m}$, pa $100 \mu \mathrm{m}$. Fore wing, length 1050 $\mu \mathrm{m}$. Tergite III lateral setae $115 \mu \mathrm{m}, 80 \mu \mathrm{m}$; tergite IX major setae $200 \mu \mathrm{m}, 225 \mu \mathrm{m}, 200$ $\mu \mathrm{m}$. Tube, length $230 \mu \mathrm{m}$. Antennal segments III-VIII length $65 \mu \mathrm{m}, 50 \mu \mathrm{m}, 65 \mu \mathrm{m}, 65 \mu \mathrm{m}$, $55 \mu \mathrm{m}, 35 \mu \mathrm{m}$.

Male macroptera: Body and legs similar to female in colour, abdomen more slender; irregular transverse pore plates present on sternites VII-VIII, usually complete medially on VIII but broader laterally, always incomplete medially on VII (Fig. 9).

Measurements (paratype male): Body length $2000 \mu \mathrm{m}$. Head, length $175 \mu \mathrm{m}$; postocular setae $60 \mu \mathrm{m}$. Tergite IX major setae 175 $\mu \mathrm{m}, 175 \mu \mathrm{m}, 170 \mu \mathrm{m}$. Tube, length $165 \mu \mathrm{m}$.

Material studied: Holotype female, Costa Rica, San José Province, Zurquí de Moravia, from leaf gall on Piper bredenmeyeri, 8.xi.2013 (S. Zamora).

Paratypes: 3 males taken with holotype; same locality and collector, 2 females from leaf gall on Piper lanosibracteum, 7.viii.2013; 2 females, 1 male from Piper sp. vein gall, 7.viii.2013, 3 females, 2 males from Piper sp. vein gall, 11.x.2013.

Diagnosis: Within the Phlaeothripinae, the genus Holopothrips is remarkable because each species exhibits at least one of the following three unusual character states: abdominal tergites with an additional pair of wing-retaining setae; males with complex pore plates on one or more abdominal sternite (Fig. 9, Fig. 10 y Fig. 11); females with a greatly enlarged spermatheca (Fig. 10, Fig. 12, Fig. 13 y Fig. 14). Of the 34 described species in this genus only four are known in which the pronotal epimera each bear two pairs of setae: conducans from Brazil, inquilinus from Guadeloupe, tillandsiae and chaconi from Costa Rica. Of these, inquilinus is bicoloured, whereas the bodies of the other three are uniformly brown. Moreover, although inquilinus was also described as breeding within old cecidomyid galls, it differs in having the spermatheca (Fig. 14) less swollen than that of chaconi (Fig. 10), and more similar to that of conducans (Fig. 13). In contrast, the spermatheca of tillandsiae is greatly elongate extending forward into the sixth abdominal segment (Fig. 12). Males of tillandsiae have no pore plates on the posterior sternites, whereas conducans has one median transverse pore plate on sternite VIII (Fig. 11). The description of inquilinus states that sternites VII and VIII each have one posterior and one anterolateral pair of pore plates, whereas chaconi has irregularly transverse pore plates medially on both VII and VIII. The head of conducans is more than 1.1 times as long as wide, with strong transverse lines across the vertex. In contrast, the head of tillandsiae is as wide as long, with almost no sculpture on the vertex, and the cheeks prominently wider just behind the eyes. The head of chaconi is intermediate between these two in shape and sculpture. Both inquilinus and conducans have three equally long stout sense cones on antennal segments III and IV. In contrast, in both tillandsiae and chaconi antennal segments III and IV have one of their three sense cones either absent or less than half as long as the two major sense cones. The new species also differs from the other three in having the pronotal anteromarginal setae very short and rarely longer than the discal setae.

\section{DISCUSSION}

The biology and host plants of most Holopothrips species are unknown, but among those species where information is available, many are associated with plant galls. Three described species appear to be gall-formers, inducing rather simple leaf deformations such as wrinkling of the leaf surface: $H$. conducans (Priesner) on Myrtaceae (Costa, 1935), $H$. claritibialis Cavalleri \& Kaminski on Mollinedia (Monimiaceae) (Cavalleri \& Kaminski, 2007), and H. tabebuia Cabrera \& Segarra on Tabebuia (Bignoniaceae) (Cabrera \& Segarra, 
2008). However, other species are not gallformers and instead they inhabit the empty galls formed by other insects. This has been reported for $H$. inquilinus, which was found inhabiting empty cecidomyiid galls on leaves of Inga (Fabaceae) (Bournier, 1993). We found a similar situation in $H$. chaconi, which colonized recently vacated leaf-vein galls formed by a cecidomyiid (Zalepidota) on certain species of Piper. Our observations that $H$. chaconi rarely left the galls and did not feed on food bodies, suggest that it feeds on tissue lining the inner cavity of empty galls. Additional studies are required to confirm this and to determine whether species such as $H$. inquilinus have similar feeding habits.

Our results suggest that eggs are laid at different times and that the empty cecidomyiid galls continue to be occupied by successive generations of thrips, possibly until the following year when new galls become available. It is also possible that at least some adult offspring remain in their maternal galls while others move, at least occasionally, between galls. Further research is needed to confirm these preliminary observations and to determine the conditions under which adult thrips move between galls, if indeed they do so. It would also be interesting to determine whether $H$. chaconi occupies abandoned galls of other gall-inducing insects on other plants. Finally, our observation that both the nymphs and adults raise the tip of their abdomen and emit a distinctive odor when disturbed is very suggestive of a chemical defense against potential predators such as ants.

\section{ACKNOWLEDGMENTS}

We would like to thank Jorge Arturo Lizano for permission to work on his property, Eduardo Chacón for identifying the Piper species, and Ray Gagné for identifying the cecidomyiid. Patricia Nel of the Muséum National d'Histoire
Naturelle, Paris kindly provided the image of the spermatheca of Holopothrips inquilinus.

\section{RESUMEN}

Biología de Holopothrips chaconi sp.n. (Thysanoptera: Phlaeothripidae) en las agallas de la hoja-vena de las especies de Piper (Piperaceae) en Costa Rica. La mayoría de las especies del género neotropical Holopothrips se asocian a las agallas de plantas pero se sabe muy poco de su biología. Aquí, se provee observaciones sobre la biología de una nueva especie de Holopothrips que se asocia a las agallas de venas foliares en cuatro especies de Piper en un bosque nuboso (Zurquí de Moravia) de Costa Rica. Esta especie coloniza las agallas luego de que el cecidómido inductor o un parasitoide del mismo emerge, y aparentemente varias generaciones de trips ocupan las agallas vacías. Un total de 175 agallas vacías en 34 hojas fueron recolectadas, llevadas al laboratorio para disección bajo el microscopio y se cuantificó su contenido. Holopothrips ocupaba aproximadamente el $75 \%$ de las hojas con agallas y en ellas el $40 \%$ de las agallas. Se encontró toda combinación de adultos, ninfas y huevos, lo cual implica que los trips adultos entran y salen y posiblemente no defienden sus agallas de la invasión de otros miembros de su especie. Sin embargo, adultos y ninfas, levantan la punta del abdomen al ser perturbados, emitiendo un olor distintivo que sugiere una reacción defensiva ante posibles depredadores. La evidencia preliminar indica que se alimentan del tejido interior de la agalla y pasan muy poco tiempo fuera de la misma. Se describe la especie nueva y es una de sólo cuatro especies conocidas de Holopothrips que poseen dos pares de setas epimorales en el pronoto. Al compararla con estas otras especies surge una marcada variación en la espermateca de la hembra y en las placas del poro esternal en el macho, los cuales se ilustran. Se requiere más investigación para confirmar la sugerencia que varias generaciones de trips ocupan las agallas vacias, para determinar si es cierto que los trips adultos se mueven entre agallas, y para explorar en más detalle la supuesta defensa química.

Palabras clave: agallas de hojas, Piper especies, Holopothrips nueva especie, estructura de espermateca.

\section{REFERENCES}

Bournier, A. (1993). Thysanoptères de Martinique et de Guadeloupe. International Journal of Pure and Applied Zoology, 3, 227-240. 
Cabrera, I., \& Segarra, A. (2008). A new gall-inducing species of Holopothrips (Thysanoptera: Phlaeothripinae) from Tabebuia trumpet trees in the Caribbean Region. Florida Entomologist, 91, 232-236.

Cavalleri, A., \& Kaminski, L. A. (2007). A new Holopothrips species (Thysanoptera: Phlaeothripidae) damaging Mollinedia (Monimiaceae) leaves in southern Brazil. Zootaxa, 1625, 61-68.

Costa, A. (1935) Tisanopterocecidias do Brasil. O Campo, 6, 25-29.

Gastreich, K. R., \& Gentry, G. L. (2004). Faunal studies in model Piper spp. systems, with a focus on spiderinduced indirect interactions and novel insect-Piper mutualisms. In L. A. Dyer, \& A. P. N. Palmer (Eds.), Piper: a model genus for studies of phytochemistry, ecology, and evolution (pp. 97-116). New York: Kluwer Academic/Pelnum Publishers.

Mound, L. A., \& Marullo, R. (1996). The Thrips of Central and South America: An Introduction. Memoirs on Entomology, International, 6, 1-488.

Risch, S. J., \& Rickson, F. R. (1981). Mutualism in which ants must be present before plants produce food bodies. Nature, 291, 149-150.

ThripsWiki (2015). ThripsWiki - providing information on the World's thrips. <http://thrips.info/wiki/Main Page $>$ [accessed 3.ix.2015] 